\title{
Kapasitas Grup Pondasi Tiang Berdasarkan NSPT Pada Abutment Jembatan
}

\author{
Encu Sutarman \\ Fakultas Teknik, Program Studi Sipil \\ Universitas Langlangbuana \\ Jl. Karapitan 116, Bandung \\ e.sutarmancivil@gmail.com
}

\begin{abstract}
Abstrak- Kegagalan bangunan jembatan, mulai dari penurunan \& kerusakan oprit, pergeseran \& keruntuhan abutmen, pilar, retak dan runtuhnya lantai jembatan dll. Daya dukung ijin abutment memenuhi kapasitas yang diijinkan terhadap beban luar serta settlement dari abutment memenuhi yang disyaratkan.

Kajian ini antara lain: daya dukung pondasi, spasi antar pondasi, hubungan kapasitas ijin pondasi tunggal terhadap kapasitas ijin group pondasi, effisiensi group dengan faktor keamanan yang disyaratkan serta settlement yang diijinkan terhadap beban rencana.

Data berdasarkan proyek ruas jalan Hantar Jatigede Sumedang yang merupakan pekerjaan PLTA Jawa Barat Tahun 2013. Pengambilan tanah asli (undistrubed) dengan cara melakukan pemboran di titik lokasi rencana pondasi akan ditempatkan, kedalaman pengambilan tanah (sampling) disesuaikan terhadap daya dukung tanah yang didapat dari standard penetration test (SPT). Pengambilan contoh tanah tidak terganggu (Undisturbed Sample) serta pengambilan contoh tanah terganggu (Disturb Sample) sesuai tujuan dan kegunaannya. Data - data tersebut antara lain ; Sifat fisis dan mekanis tanah undisturbed serta NSPT dari Lokasi BW 01 under bridge abutment Jl. Hantar PLTA Jatigede.

Analisa daya dukung pondasi berdasarkan SPT metode Meyerhof, 1976. Hasil analisa bahwa pondasi tiang pancang maupun bor pile memberikan daya dukung yang lebih besar dibandingkan dengan beban rencana. Settlement akibat beban luar lebih kecil dari settlement yang diijinkan.

Mengingat begitu pentingnya data parameter tanah yang menjadi dasar perhitungan tentunya data tersebut harus dihasilkan dengan kondisi actual serta metode yang benar.
\end{abstract}

Kata kunci-Soil test, parameter tanah, metode analitis, empiris, driven pile, drilled pile, pile group, end bearing capacity, friction capacity, ultimate capacity, safety factor, allowable capacity, settlement.

\section{Pendahuluan}

\section{A. Latar Belakang Dan Permasalahan}

Kegagalan bangunan jembatan, berupa penurunan, pergeseran \& keruntuhan abutment dan pilar disebabkan oleh beban berlebih, gerusan air, gempa, longsoran serta daya dukung tanah di daerah abutment dan pilar tidak memenuhi.

Tanah terbebani jika konstruksi didirikan dan jika tanah tidak tahan akibat tekanan vertical akibat konstruksi akan menyebabkan penurunan (settlement), hal ini menyebabkan unstabilitas konstruksi setelah pondasi tersebut menerima beban konstruksi. Tentunya perlu perencanaan teknik pondasi yang baik serta penting untuk mengetahui kapasitas atau daya dukung ijin tanah, beban yang tersalurkan pondasi ketanah itu sehubungan dengan beban rencana yang akan bekerja. Jika tidak, maka hal ini menyebabkan unstabilitas yang akan membahayakan pengguna konstruksi serta masyarakat sekitar.

Apakah daya dukung pondasi abutment memenuhi kapasitas ijin terhadap beban luar serta settlement dari pondasi memenuhi yang diijinkan?

\section{B. Maksud Kajian}

Maksud kajian ini yaitu untuk mendapatkan suatu informasi mengenai apa yang menjadi permasalahan diatas tentang :

a. Daya dukung ijin pondasi tunggal.

b. Daya dukung ijin pile group dengan jarak spasi maksimal.

c. Settlement yang diijinkan serta settlement akibat beban luar.

\section{Tujuan Kajian}

Kajian ini untuk dapat menentukan suatu desain pondasi itu sesuai parameter tanah serta beban maksimum rencana serta bertujuan untuk mengetahui factor yang berpengaruh terhadap daya dukung tanah yang diijinkan.

\section{LANDASAN TEORI}

\section{A. Uji Penetrasi Standard (SPT)}

Uji penetrasi standard (SPT) mulai dikembangkan tahun 1927 yang merupakan sarana untuk mendapatkan informasi dari lapisan bawah permukaan tanah, metode ini tidak hanya populer juga ekonomis.

Cara ini telah dibakukan sebagai ASTM (American Standard for Testing and Materials) D 1586 sejak tahun 1958 sampai sekarang.

Pengujian SPT terdiri dari :

a. Pemancangan alat pengambil contoh tanah berupa selinder belah standard atau tabung split spoon.

b. Perhitungan banyaknya pukulan untuk memasukan tabung split spoon sepanjang $30,5 \mathrm{~cm}(12$ inci $\approx 1 \mathrm{ft})$ yang terakhir untuk bilangan N SPT.

c. Dengan menggunakan massa palu/ hammer $140 \mathrm{lbs}(63,5$ $\mathrm{kg})$ yang jatuh bebas dari ketinggian 30 inc $(76 \mathrm{~cm})$ 
Yang dimaksud tabung split spoon yaitu sebuah tabung berdiameter luar 2 inc $(5,08 \mathrm{~cm})$ dan berdiameter dalam 1,5 inc $(3,81 \mathrm{~cm})$, panjang $18 \mathrm{inc}-30$ inc $(45,7 \mathrm{~cm}-76,2 \mathrm{~cm})$.

Pipa bor yang dipakai untuk menyambung penumbuk ke split spoon di dalam tanah adalah pipa A berdiameter $13 / 8$ inc $(4,12 \mathrm{~cm})$ dan diameter dalam $9 / 8$ inc $(2,85 \mathrm{~cm})$ atau yang lebih besar.

Definisi dari NSPT yaitu jumlah tumbukan yang diperlukan untuk memasukan tabung split spoon baku ke dalam tanah sedalam 1 foot atau $30 \mathrm{~cm}$, setelah masuk sedalam $15 \mathrm{~cm}$ atau $1 / 2 \mathrm{ft}$ pertama disebut nilai $\mathrm{N}$ atau NSPT. Uji ini dilakukan bersama - sama dengan boring.

Hasil SPT dari berbagai kedalaman dari satu lobang bor dapat digambarkan grafik SPT terhadap kedalaman yang biasanya bersatu dengan bor log. Hasil SPT dapat dipakai sebagai analisis pendahuluan, pembanding analisis dari hasil lab tanah asli, dapat memperkirakan parameter tanah asli hasil uji lab.

Para peneliti geoteknik telah banyak membuat korelasi SPT dengan: uji lapangan lainnya, berbagai sifat tanah seperti dengan jenis tanah serta konsistensinya, kuat geser tanah, parameter consolidasi, relatif density pasir, daya dukung pondasi, dan lain-lain.

Seperti yang ditunjukan Tabel 1, yang mana nilai dari NSPT dapat untuk menentukan modulus elastisitas tanah atau modulus tegangan - regangan Es.

TABEL 1. PERSAMAAN UNTUK MENDAPATKAN NILAI MODULUS TEGANGAN REGANGAN ES

\begin{tabular}{|c|c|}
\hline Jenis tanah & SPT \\
\hline Pasir normally consolidated & $\begin{array}{l}E s=500(N+15) \\
E s=1500 \ln N \text { to } 2200 \ln N\end{array}$ \\
\hline Pasir over consolidated & $\begin{array}{l}\dagger \mathrm{Es}=18000+750 \mathrm{~N} \\
\mathrm{Es}(\mathrm{OCR})=\mathrm{Es}(\mathrm{NC})(\mathrm{OCR}) 0,5\end{array}$ \\
\hline Pasir jenuh & $\mathrm{Es}=250(\mathrm{~N}+15)$ \\
\hline \multirow{3}{*}{ Pasir berkerikil dan kerikil } & $E s=1200(N+6)$ \\
\hline & $E s=600(N+6)$ jika $N \leq 15$ \\
\hline & $\begin{array}{l}\text { Es }=600(N+6)+2000 \\
\text { Jika } N>15\end{array}$ \\
\hline Pasir berlempung & $E s=320(N+15)$ \\
\hline Pasir berlanau & $E s=300(N+6)$ \\
\hline Lempung lunak & \\
\hline
\end{tabular}

Pengujian dihentikan bila;

a. Diperlukan 50 kali pukulan untuk setiap penambahan kedalaman $15 \mathrm{~cm}$.

b. Telah tercapai 100 kali pukulan.

c. 10 kali pukulan berturut tidak menunjukan kemajuan.

Untuk lebih jelasnya perhatikan Gambar 1 :

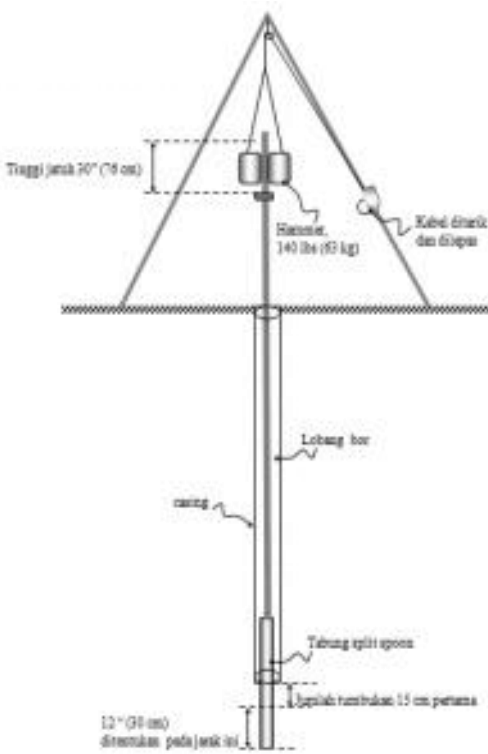

Gambar 1. Uji penetrasi standard (SPT)

\section{B. Daya Dukung Pondasi Berdasarkan Uji Penetrasi Standard Meyerhof Method's, 1976}

\section{End Bearing Capacity}

Daya dukung batas (ultimate) ujung pondasi tiang untuk pondasi tiang pancang (driven pile) Qp dalam tons berdasarkan data SPT atau NSPT dinyatakan oleh persamaan:

Untuk tanah pasir:

$Q_{p}=\frac{0,4 N^{\prime}}{B} \quad D_{f} A_{p} \leq 4 N^{\prime} A_{p}$

Untuk tanah silt ;

$Q_{p}=\frac{0,4 N^{\prime}}{B} \quad D_{f} A_{p} \leq 3 N^{\prime} A_{p}$

$\mathrm{N}^{\prime}=\mathrm{C}_{\mathrm{N}} \mathrm{N}_{\mathrm{av}}$

$\mathrm{C}_{\mathrm{N}}=0,77 \log \frac{20}{\sigma^{\prime} \mathrm{v}}$

Syarat $\sigma^{\prime} \mathrm{v} \geq 0,25$ tsf $\left(\mathrm{tsf}=\right.$ ton $\left./ \mathrm{ft}^{2}\right)$

Yang mana:

$\mathrm{Q}_{\mathrm{p}}$ : Daya dukung batas ujung pondasi tiang dalam tons.

N' : NSPT rata - rata terkoreksi.

B : diameter tiang pondasi.

$\mathrm{D}_{\mathrm{f}}$ : panjang pondasi

$A_{p}$ : luas penampang ujung pondasi.

$\mathrm{C}_{\mathrm{N}}$ : koef koreksi, rekomendasi Peck et al (1974).

$\mathrm{N}_{\mathrm{av}}$ : NSPT rata - rata.

$\sigma_{\mathrm{v}}^{\prime}$ : tekanan effektif vertical in tsf 
Persamaan di atas dapat digunakan untuk data DCPT rekomendasi Canadian Foundation Engineering Manual, 1985.

\section{Friction Capacity (Meyerhof 1976, 1982)}

Daya dukung batas (ultimate) keliling tiang pondasi untuk pondasi tiang pancang (driven pile) Qf dalam tons berdasarkan data SPT atau NSPT dinyatakan oleh persamaan:

$\mathrm{Q}_{\mathrm{f}}=\mathrm{f}_{\mathrm{s}} \mathrm{pL}$

$\mathrm{f}_{\mathrm{s}}=\mathrm{N}^{\prime} / 50 \leq 1 \mathrm{tsf}$

Yang mana:

$\mathrm{Q}_{\mathrm{f}}$ : Daya dukung batas keliling tiang pondasi, dalam tons.

N' : NSPT rata - rata terkoreksi.

$\mathrm{p} \quad$ : keliling tiang pondasi

L : panjang pondasi

\section{Daya Dukung Ijin Pondasi atau Qall}

Daya dukung ijin pondasi merupakan daya dukung pondasi atau lebih tepatnya daya dukung dari tanah terhadap beban rencana yang disalurkan melalui pondasi setelah memasukan faktor keamanan (SF).

Daya dukung batas pondasi atau $\mathrm{Q}_{\text {ult }}$

$\mathrm{Qult}_{\mathrm{u}}=\mathrm{Q}_{\mathrm{p}}+\mathrm{Q}_{\mathrm{f}}$

Daya dukung ijin pondasi atau $Q_{\text {all }}$

$\mathrm{Q}_{\text {all }}=\mathrm{Q}_{\mathrm{ult}} / \mathrm{SF}$

4. Daya Dukung Pondasi Group Berdasarkan Analisa Group.

$\left(Q_{v G}\right)_{u l t}=c_{u} N_{c}\left(b^{\prime}\right)^{2}+4 c_{u} b^{\prime} l_{e}$

5. Daya Dukung Pondasi Group Berdasarkan Analisa Tiang Tunggal.

$\left(Q_{v G}\right)_{u l t}=G_{e} n Q_{\text {v ult }}$

Perhatikan Gambar 2 dan Gambar 3 di bawah ini:

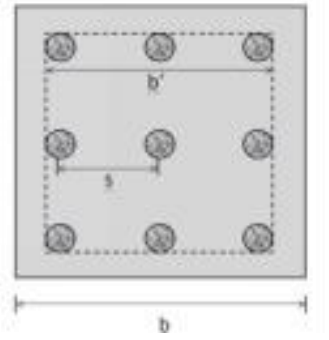

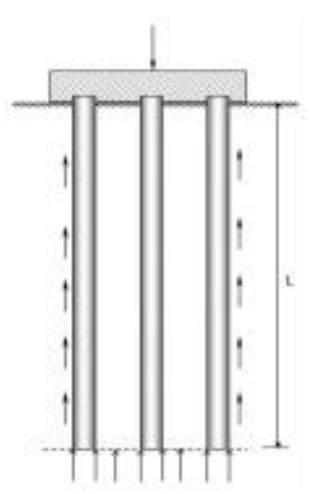

Gambar 3. Skema Group Pondasi

Yang mana:

$\left(\mathrm{Q}_{\mathrm{vG}}\right)_{\mathrm{ult}}$ : daya dukung batas group pondasi berdasarkan beban vertical.

$\mathrm{c}_{\mathrm{u}} \quad$ : kuat geser tanah cohesive.

$\mathrm{N}_{\mathrm{c}}$ : paktor daya dukung.

$\mathrm{G}_{\mathrm{e}}$ : effesiensi group.

b' : jarak luar antar pondasi.

$l_{\mathrm{e}} \quad$ : panjang effektif pondasi.

S : jarak antar center pondasi

B : diameter pondasi.

b : panjang pile cap.

$\mathrm{n} \quad$ : jumlah pondasi satu group.

Dalam hal perhitungan daya dukung pondasi group dengan perhitungan daya dukung pondasi tunggal di tanah cohesive harus dikalikan dengan jumlah pondasi yang ada dalam satu group serta dikalikan dengan faktor effesiensi group.

Faktor effesiensi group $\mathrm{G}_{\mathrm{e}}$ diperlihatkan oleh Tabel 2.

TABEL 2. FAKTOR EFFESIENSI GROUP $\mathrm{G}_{\mathrm{E}}$

\begin{tabular}{|l|l|l|l|l|l|}
\hline Pile spacing (s) & 3B & 4B & 5B & 6B & 8B \\
\hline Effesiensi Group & 0,7 & 0,75 & 0,85 & 0,9 & 1,0 \\
\hline
\end{tabular}

\section{Metodologi Penelitian dan Parameter Tanah}

Bahan untuk dikaji dan diketahui antara lain :

1. Sifat - sifat fisis, konsistensi serta parameter kuat geser tanah.

2. Sistem instalasi, dimensi pondasi. 


\section{Pengambilan Data}

Metode pengambilan informasi pendahuluan dari data SPT yang dilengkapi bor log, data sifat fisis tanah, batas - batas Atterberg tanah. Metode pengambilan tanah asli (undistrubed) dengan cara melakukan pemboran di titik lokasi rencana pondasi yang akan ditempatkan.

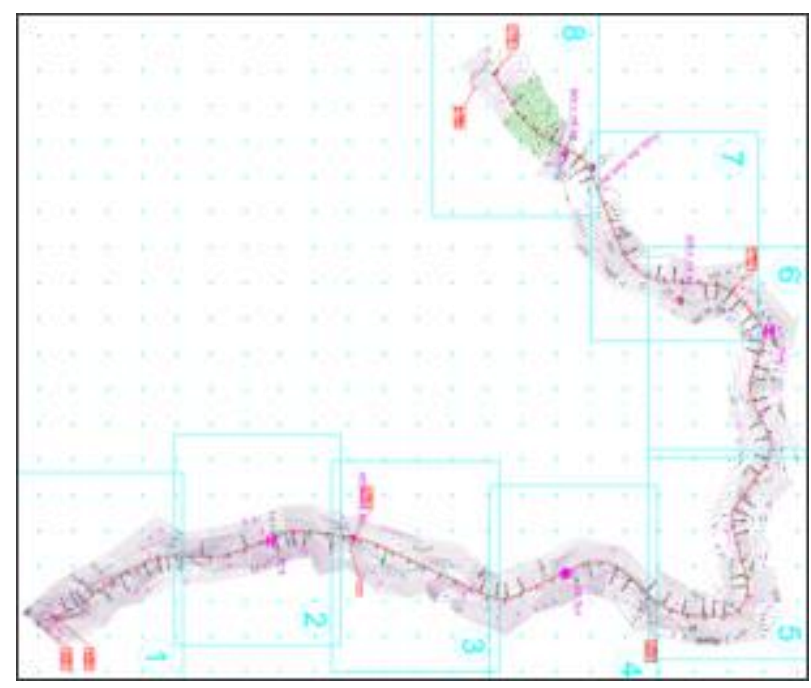

Gambar 4. Peta lokasi Jalan Hantar Jatigede

\section{E. Analisa Data}

Perhitungan - perhitungan tersebut antara lain :

1. Karakteristik serta consistensi dari tanah berdasarkan SPT.

2. Pengaruh beban vertical terhadap daya dukung ijin pondasi tunggal (single pile).

3. Pengaruh dimensi pondasi, jarak spasi antar pondasi terhadap daya dukung ijin group pondasi.

\section{F. Pengujian Lapangan Berdasarkan SPT}

Cara kerja dari SPT sebagai berikut ;

1. Lakukan pemboran sampai kedalaman yang mana akan dilakukan uji SPT, bersihkan dari serpih - serpih tanah lepas.

2. Pasang split spoon pada pipa bor dan masukan ke dalam lobang bor yang telah dilakukan.

3. Pada bagian atas dari pipa bor pasangkan hammer beserta bagian - bagian pelengkapnya yang terdiri ; hammer fall guide, hammer lifter rops (tali pengangkat hammer).

4. Lakukan penumbukan sehingga spit spoon masuk (ter penetrasi) sedalam $3 \times 6$ " atau $3 \times 15 \mathrm{~cm}$ dan hitung tumbukan untuk $15 \mathrm{~cm}$ pertama, kedua dan ketiga. Selama penumbukan jarak jatuh hammer harus tetap 30 inc dan tali pengangkat hammer harus kendor selama hammer jatuh.

5. Jumlah tumbukan pertama (15 $\mathrm{cm}$ pertama) diabaikan karena dianggap tanah rusak akibat pemboran sedangkan jumlah tumbukan hammer $15 \mathrm{~cm}$ kedua dan ketiga disebut
NSPT. Jumlah tumbukan $15 \mathrm{~cm}$ pertama dihitung jika jumlah tumbukan hammer $15 \mathrm{~cm}$ ketiga tidak bisa dilakukan.

6. Angkat tabung split spoon ke permukaan tanah dan keluarkan tanah dari tabung split spoon dengan membuka sekrup sepatu pipa dan membuka kedua belahan tabung split spoon untuk diidentifikasi, kemudian tanah disimpan di dalam core box.

7. Selanjutnya bor diperdalam untuk melakukan tes SPT berikutnya.

\section{G. Parameter Tanah}

Berdasarkan hasil SPT ditunjukan bor log yang ditunjukan oleh Gambar 5, Gambar 6, Gambar 7 yang tabelkan pada Tabel 3.

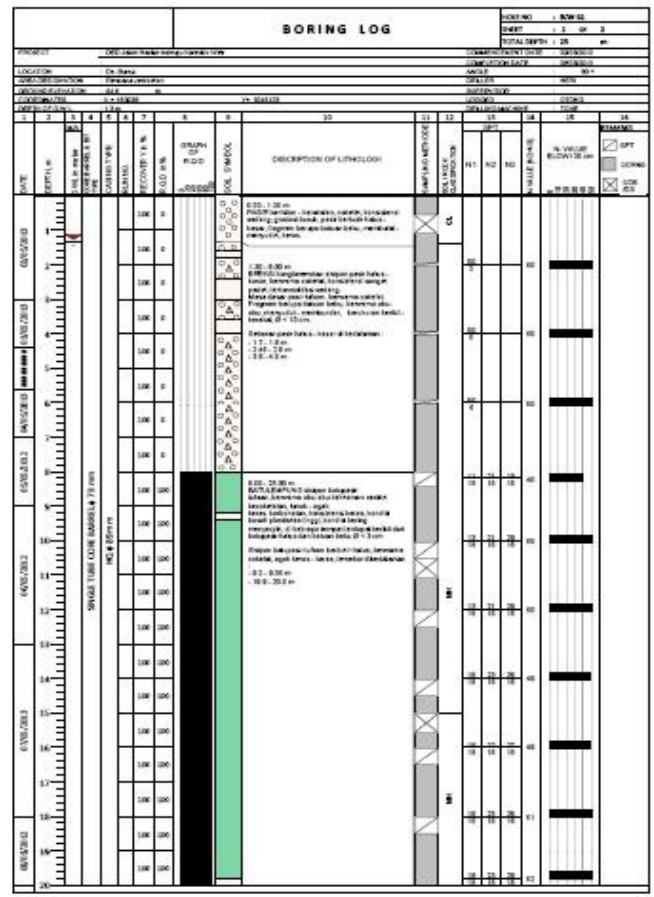

Gambar 5. Bor log NSPT BW 01 Jl. Hantar PLTA Jatigede 


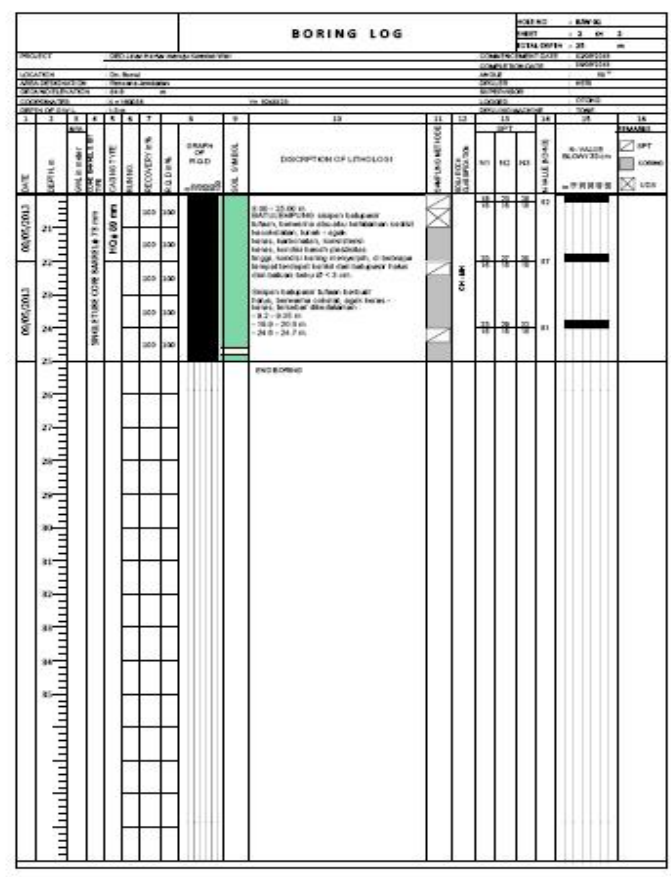

Gambar 6. Bor log NSPT BW 01 Jl. Hantar PLTA Jatigede

Gambar 7 dibawah ini merupakan jenis lapisan tanah di lokasi pelaksanaan SPT.

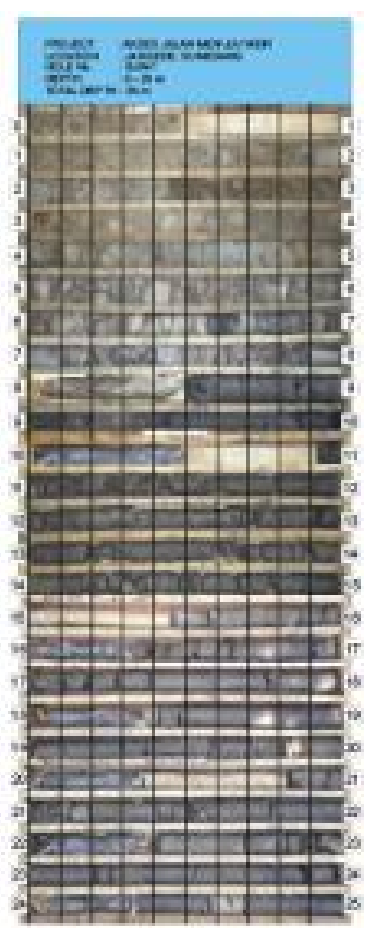

Gambar 7. Jenis Lapisan Tanah BW 01 Jl. Hantar PLTA Jatigede
TABEL 3. N SPT

Lokasi: BW 01 Jl. Hantar PLTA Jatigede

\begin{tabular}{|c|c|}
\hline Depth (m) & N SPT \\
\hline 0 & 0 \\
\hline 2 & 50 \\
\hline 4 & 50 \\
\hline 6 & 50 \\
\hline 8 & 40 \\
\hline 10 & 50 \\
\hline 12 & 50 \\
\hline 14 & 49 \\
\hline 16 & 49 \\
\hline 18 & 51 \\
\hline 20 & 52 \\
\hline 22 & 57 \\
\hline 24 & 61 \\
\hline
\end{tabular}

Berdasarkan hasil test di Laboratorium mektan ditunjukan pada Tabel 4

TABEL 4. SIFAT PHISIS DAN MEKANIS TANAH

Lokasi : BW $01 \mathrm{Jl}$. Hantar PLTA Jatigede

Depth $\quad: 20,45-20,95 \mathrm{~m}$

\begin{tabular}{|c|c|c|c|}
\hline $\begin{array}{c}\text { Jenis } \\
\text { Parameter }\end{array}$ & Notasi & Satuan & Besar Parameter \\
\hline Wet density & $\gamma$ & $\mathrm{T} / \mathrm{m}^{3}$ & 1,90 \\
\hline Kadar air & $\mathrm{w}$ & $\%$ & 30,38 \\
\hline Dry density & $\gamma_{s}$ & $\mathrm{~T} / \mathrm{m}^{3}$ & 1,458 \\
\hline Void ratio & e & - & 0,83 \\
\hline Porositas & $\mathrm{n}$ & - & 0,45 \\
\hline Berat jenis & $\mathrm{G}_{3}$ & - & 2,67 \\
\hline $\begin{array}{c}\text { Derajat } \\
\text { kejenuhan }\end{array}$ & $\mathrm{S}_{\mathrm{s}}$ & $\%$ & 97,41 \\
\hline Batas cair & $\mathrm{L}_{1}$ & $\%$ & 61,91 \\
\hline Batas Plastis & $P_{1}$ & $\%$ & 28,62 \\
\hline $\begin{array}{c}\text { Indeks } \\
\text { Plastisitas }\end{array}$ & IP & $\%$ & 33,29 \\
\hline Unconfined & qu & $\mathrm{Kg} / \mathrm{cm}^{2}$ & 1,224 \\
\hline \multirow[t]{2}{*}{ Compression } & $\mathrm{cu}$ & $\mathrm{Kg} / \mathrm{cm}^{2}$ & 0,612 \\
\hline & $\mathrm{qu}^{\prime}$ & $\mathrm{Kg} / \mathrm{cm}^{2}$ & 0,732 \\
\hline \multirow{2}{*}{ Triaxial UU } & c & $\mathrm{kg} / \mathrm{cm}^{2}$ & 0,682 \\
\hline & $\varphi$ & $\circ$ & 18,97 \\
\hline \multirow{2}{*}{$\begin{array}{c}\text { Consolidasi } \\
\text { Test }\end{array}$} & $c_{\mathrm{v}}$ & $\mathrm{cm}^{2} /$ detik & $5.959,10^{-4}$ \\
\hline & $\mathrm{c}_{\mathrm{e}}$ & & 0,2073 \\
\hline \multirow{2}{*}{ Grain size } & Sand $(\%)$ & Silt (\%) & Clay $(\%)$ \\
\hline & 1,02 & 78,39 & 20,59 \\
\hline
\end{tabular}


TABEL 5. SUMMARY OF LABORATORY TEST RESULT

Lokasi : Jl. Hantar PLTA Jatigede

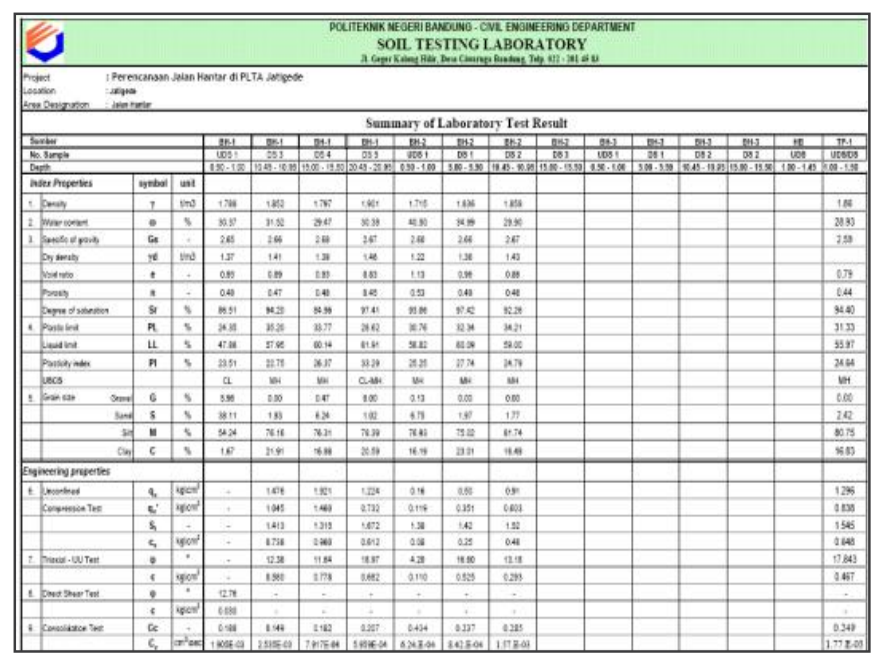

III. ANALISA DAN PEMBAHASAN

A. Analisa Daya Dukung Pondasi Tunggal Berdasarkan Uji Penetrasi Standard (SPT) Meyerhof Method's, 1976

Ujung tertutup (closed ended). Bahan pondasi terbuat dari beton. Pondasi menembus lapisan silt

Pondasi tiang berdasarkan insvestigasi lapangan ditunjukan oleh Gambar 1.4:

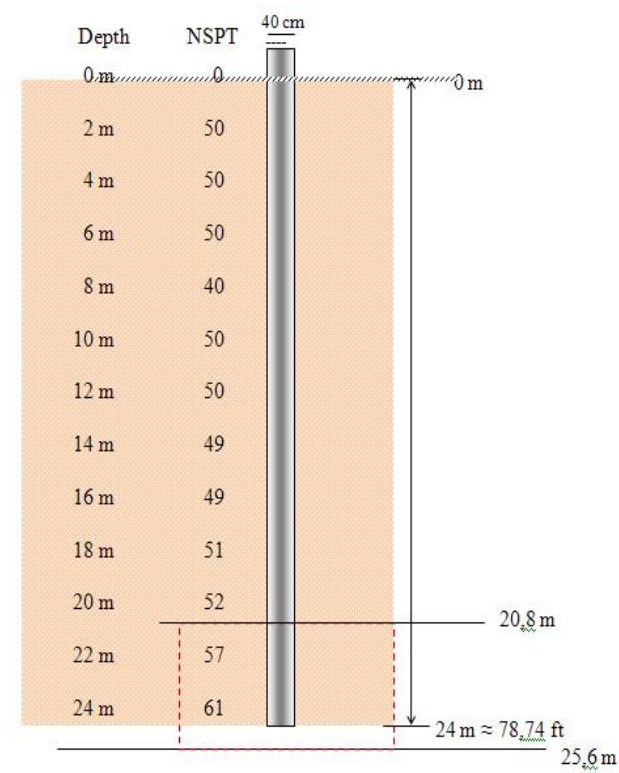

Gambar 8. Dimensi pondasi tiang dan data SPT

End Bearing Capacity Pondasi Tiang Pancang

Daya dukung batas (ultimate) ujung pondasi tiang untuk pondasi tiang pancang (driven pile) $\mathrm{Q}_{\mathrm{p}}$ dalam tons berdasarkan data SPT atau $\mathrm{N}_{\mathrm{SPT}}$ dinyatakan oleh persamaan tanah silt:
Tegangan effektif

\begin{tabular}{|c|c|c|c|c|c|}
\hline $\mathrm{h}(\mathrm{m})$ & $\mathrm{h}(\mathrm{ft})$ & $\gamma^{\prime} \mathrm{Lbs} / \mathrm{ft}^{3}$ & $\mathrm{Lbs} / \mathrm{ft}^{2}$ & $\mathrm{Ton} / \mathrm{ft}^{2}$ & $\mathrm{kN} / \mathrm{m}^{2}$ \\
\hline 23.00 & 75.46 & 56.09 & 4232.63 & 1.92 & 428.47 \\
\hline
\end{tabular}

Dikedalaman 0,5 m-1 m

Dry density $\gamma=1,372 \mathrm{~T} / \mathrm{m}^{3}$

Kadar air $=30,37 \%$

GWT $1 \mathrm{~m}$ dari permukaan

Jadi teg eff $=2,05$ Tsf

factor koreksi :

$\mathrm{C}_{\mathrm{N}}=0,77 \log \frac{20}{\sigma_{\mathrm{v}}^{\prime}}=0,77 \log \frac{20}{2,05}=0.76$

Syarat $\sigma_{v}^{\prime} \geq 0,25$ tsf $\quad\left(t s f=t o n / f t^{2}\right)$

$\mathrm{N}_{\text {rata - rata }}\left(\mathrm{N}_{\mathrm{av}}\right)$ untuk end bearing capacity

Untuk menentukan $\mathrm{N}_{\text {rata-rata }}$ tentukan $\mathrm{N}$ pada jarak $8 \mathrm{~B}$ keatas dan 4B kebawah dari ujung

pondasi (pile tip).

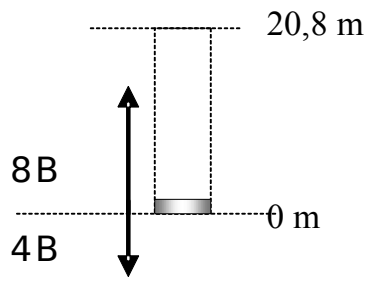

Ujung pondasi berada dikedalaman $197 \mathrm{ft}$, untuk Nav gunakan di kedalaman; L -8 B sampai

$\mathrm{L}+4 \mathrm{~B}$ antara $20,8 \mathrm{~m}$ sd $25,6 \mathrm{~m}$

$\mathrm{N}_{\text {av }}$ yang diperhitungkan dalam rentang $68,244 \mathrm{ft}-83,99 \mathrm{ft}$. atau $20,8 \mathrm{~m}-25,6 \mathrm{ft}$

$\mathrm{N}_{\mathrm{av}}=(52+57+61) / 3=56,7$

$\mathrm{N}^{\prime}=\mathrm{C}_{\mathrm{N}} \mathrm{N}_{\mathrm{av}}=0,76(56,7)=43$

$\mathrm{A}_{\mathrm{p}}=\pi \mathrm{B}^{2} / 4=3,14 \cdot 1,312^{2} / 4=1,35 \mathrm{ft}^{2}$

$\mathrm{Q}_{\mathrm{p} 1}=1393,55$ Ton

$\mathrm{Q}_{\mathrm{p} 2}=174,15$ Ton

$\mathrm{Q}_{\mathrm{p} 1}>\mathrm{Q}_{\mathrm{p} 2}$

gunakan dalam hal ini $\mathrm{Q}_{\mathrm{p} 2}=174,15$ Ton

Sedangkan End Bearing Capacity pondasi bor.

$\mathrm{Q}_{\mathrm{pb}}=(1 / 3) 174,15$ Ton $=58.05$ Ton

Friction Capacity Pondasi Tiang Pancang

Pondasi untuk pondasi tiang pancang (driven pile) $\mathrm{Q}_{\mathrm{f}}$ dalam tons berdasarkan data SPT;

$\mathrm{f}_{\mathrm{s}}=\mathrm{N}^{\prime} / 50 \leq 1$ tsf 
factor koreksi ;

$\mathrm{C}_{\mathrm{N}}=0,0,993$

$\mathrm{N}_{\text {rata - rata }}\left(\mathrm{N}_{\mathrm{av}}\right)$ untuk Friction Capacity

$\mathrm{N}_{\mathrm{av}}$ merupakan besar $\mathrm{N}$ sepanjang tiang dibagi jumlah $\mathrm{N}$

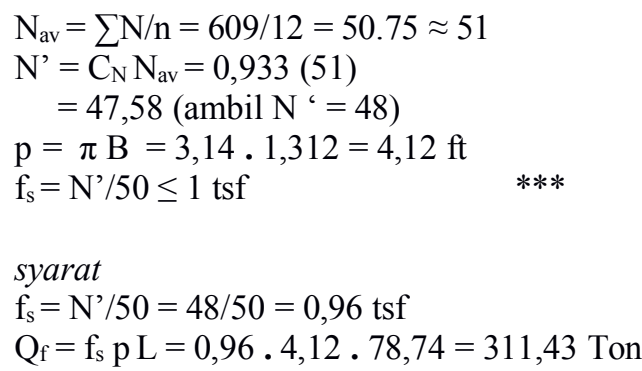

Sedangkan Friction Capacity Pondasi Bor.

$\mathrm{Q}_{\mathrm{fb}}=(1 / 2) 311,43$ Ton $=155.715$ Ton

\section{Daya Dukung Batas Pondasi Tiang}

1. Daya dukung batas/ ultimate pondasi atau $Q_{u l t}$ pondasi tiang pancang;

$\mathrm{Q}_{\text {ult }}=\mathrm{Q}_{\mathrm{p}}+\mathrm{Q}_{\mathrm{f}}=485,58$ Ton

2. Daya dukung batas/ ultimate pondasi atau $\mathrm{Qult}_{\text {pondasi }}$ bor pile;

$\mathrm{Q}_{\text {ult }}=\mathrm{Q}_{\mathrm{p}}+\mathrm{Q}_{\mathrm{f}}=213.765$ Ton

3. Daya dukung ijin pondasi tiang pancang (allowable) atau Qall

$\mathrm{SF}=3$ maka $\mathrm{Q}_{\text {all }}=\mathrm{Q}_{\text {ult }} / \mathrm{SF}=162$ Ton

4. Daya dukung ijin pondasi pondasi bor pile (allowable) atau $Q_{\text {all }}$

$\mathrm{SF}=3$ maka $\mathrm{Q}_{\text {all }}=\mathrm{Q}_{\mathrm{ult}} / \mathrm{SF}=71$ Ton

\section{B. Daya Dukung Group Pondasi Tiang Pancang}

1. Daya dukung batas/ ultimate pondasi group tiang pancang atau $\mathrm{Q}_{\text {ult }} \mathrm{G}$

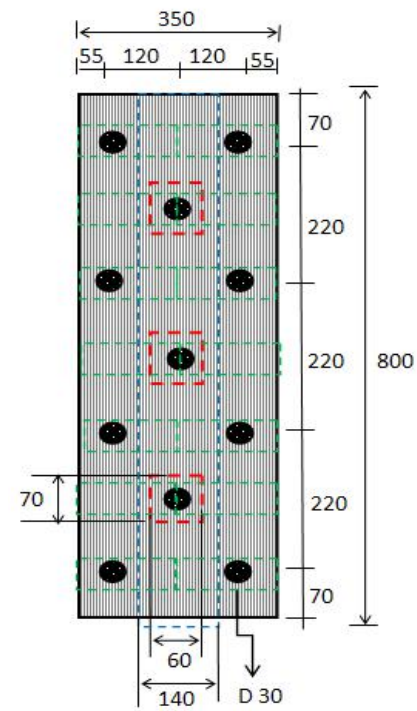

Gambar 9. Configurasi Group Pondasi

Dalam hal perhitungan daya dukung pondasi group dengan perhitungan daya dukung pondasi tunggal di tanah cohesive harus dikalikan dengan jumlah pondasi yang ada dalam satu group serta dikalikan dengan faktor effesiensi group. Faktor effesiensi group $\mathrm{G}_{\mathrm{e}}$

Pile spacing (s) : $2,4 \mathrm{~m}=6 \mathrm{~B}$

Effesiensi Group $\left(\mathrm{G}_{\mathrm{e}}\right)=0,9$

Jumlah pondasi dalam satu group

(n) $=11$

$\left(\mathrm{Q}_{\mathrm{vG}}\right)_{\mathrm{ult}}=\mathrm{G}_{\mathrm{e}} \mathrm{n} \mathrm{Q}_{\mathrm{v} \text { ult }}$ $=0,9 \cdot 11 \cdot 485,58$ Ton $=4807$ Ton.

2. Daya dukung batas/ ultimate pondasi pondasi bor pile atau Qult

$$
\begin{aligned}
\left(Q_{v G}\right)_{\text {ult }} & =G_{e} n Q_{v} \text { ult } \\
& =0,9 \cdot 11 \cdot 213.765 \text { Ton } \\
& =2116 \cdot 27 \text { Ton }
\end{aligned}
$$

3. Daya dukung ijin pondasi tiang pancang group atau $\mathrm{Q}_{\text {ult }}$, $\mathrm{SF}=3$

$\mathrm{Q}_{\mathrm{G} \text { all }}=1602,4$ Ton

4. Daya dukung ijin pondasi group pondasi bor $\mathrm{Qult}_{\text {ult }} \mathrm{SF}=3$ $\mathrm{Q}_{\mathrm{G} \text { all }}=705.42 \mathrm{Ton}$ 
1. Settlement pondasi tiang pancang tunggal yang diijinkan

Sall

Modulus elastisitas beton

$\mathrm{E}_{\mathrm{b}}=3,6 \cdot 10^{6} \mathrm{psi}$

$\mathrm{Q}_{\mathrm{all}}=162 \mathrm{Ton}=356907 \mathrm{lbs}$

$\mathrm{B}=0.40 \mathrm{~m}=15,748 \mathrm{inc}$

$\mathrm{L}_{\mathrm{e}}=24 \mathrm{~m} \approx 945 \mathrm{inc}$

$\mathrm{A}_{\mathrm{p}}=194,7$ inc $^{2}$

Penurunan ijin pondasi berdasarkan metoda empiris

(Vesic 1970), $\mathrm{S}_{\text {all }}$;

$\mathrm{S}_{\text {all }}=0,64$ inc $\approx 1,62 \mathrm{~cm}$

2. Settlement pondasi bor tunggal yang diijinkan $S_{\text {all }}$

Modulus elastisitas beton

$\mathrm{E}_{\mathrm{b}}=3,6 \cdot 10^{6} \mathrm{psi}$

$\mathrm{Q}_{\text {all }}=71 \mathrm{Ton}=156984 \mathrm{lbs}$

$\mathrm{B}=0.40 \mathrm{~m}=15,748 \mathrm{inc}$

$\mathrm{L}_{\mathrm{e}}=24 \mathrm{~m} \approx 945 \mathrm{inc}$

$\mathrm{A}_{\mathrm{p}}=194,7$ inc $^{2}$

Penurunan ijin pondasi berdasarkan metoda empiris

(Vesic 1970), $S_{\text {all }}$;

$\mathrm{S}_{\mathrm{all}}=0.94 \mathrm{~cm}$

3. Settlement single pile akibat beban luar

$\mathrm{N}=31,273$ Ton $\approx 68898,5$ Lbs

$\mathrm{S}=0,25 \mathrm{inc} \approx 0,63 \mathrm{~cm}$

\section{Settlement Group Pondasi Tiang}

1. Settlement group pondasi tiang pancang

$\mathrm{S}_{\text {all G }}$

$\mathrm{S}_{\text {all G }}=\mathrm{S}_{\text {all }}\left(\mathrm{b}^{\prime} / \mathrm{B}\right)^{0,5}$

$\mathrm{b}^{\prime}=7 \mathrm{~m} \approx 275,6$ inc

$\mathrm{B}=0.40 \mathrm{~m}=15,748$ inc

$b^{\prime}=$ jarak luar antar pondasi

Maka settlement;

$$
\begin{aligned}
\mathrm{S}_{\text {all G }} & =\mathrm{S}_{\text {all }}\left(\mathrm{b}^{\prime} / \mathrm{B}\right) 0,5 \\
& =0,64(275,6 / 15,748)^{0,5} \\
& =2,68 \mathrm{inc} \approx 6,81 \mathrm{~cm}
\end{aligned}
$$

2. Settlement group pondasi bor yang diijinkan $\mathrm{S}_{\text {all G }}$

$\mathrm{S}_{\text {all G }}=\mathrm{S}_{\text {all }}\left(\mathrm{b}^{\prime} / \mathrm{B}\right)^{0,5}$

$\mathrm{b}^{\prime}=7 \mathrm{~m} \approx 275,6$ inc

$\mathrm{B}=0.40 \mathrm{~m}=15,748 \mathrm{inc}$

maka settlement pile group;

$\mathrm{S}_{\text {all G }}=\mathrm{S}_{\text {all }}\left(\mathrm{b}^{\prime} / \mathrm{B}\right)^{0,5}$

\section{Kesimpulan dAN SARAN}

A. Kesimpulan

Pondasi Tiang Pancang, $S F=3$

1. Daya dukung pondasi tiang Pancang tunggal lebih besar dari beban rencana ;

$\mathrm{Q}_{\text {all }}>\mathrm{N}=162$ Ton $>31,273$ Ton

2. Daya dukung ijin group pondasi tiang pancang lebih besar dari beban luar group;

Qall G $>3 \mathrm{~N}$---1602,4 Ton $>93,82$ Ton

3. Settlement pondasi tiang pancang

akibat beban luar pondasi tiang tunggal lebih kecil dari

Settlemen ijin pondasi tiang tunggal;

$\mathrm{S}<\mathrm{S}_{\text {all }}---0,63 \mathrm{~cm}<1,62 \mathrm{~cm}$

4. Settlement pondasi group tiang pancang akibat beban luar;

Settlement group tiang akibat beban lebih kecil dari

Settlement ijin group tiang;

$\mathrm{S}_{\mathrm{G}}<\mathrm{S}_{\text {all G- }}----2,66 \mathrm{~cm}<6,81 \mathrm{~cm}$

5. Settlement group tiang akibat beban luar

$\mathrm{S}_{\mathrm{G}}=\mathrm{S}\left(\mathrm{b}^{\prime} / \mathrm{B}\right)^{0,5}$

$\mathrm{b}^{\prime}=7 \mathrm{~m} \approx 275,6$ inc

$$
\begin{gathered}
\mathrm{B}=0.40 \mathrm{~m}=15,748 \text { inc } \\
\text { serta } \mathrm{S}=0,25 \text { inc }
\end{gathered}
$$

maka settlement group tiang;

$$
\begin{aligned}
\mathrm{S}_{\mathrm{G}} & \left.=\mathrm{S}\left(\mathrm{b}^{\prime} / \mathrm{B}\right)\right)^{0,5} \\
& =0,25(275,6 / 15,748)^{0,5} \\
& =1,046 \text { inc } \approx 2,66 \mathrm{~cm}
\end{aligned}
$$

Pondasi Bor, $S F=3$

1. Daya dukung ijin pondasi tiang bor tunggal lebih besar dari beban rencana:

$\mathrm{Q}_{\text {all }}>\mathrm{N}$---- 71 Ton $>31,273$ Ton

2. Daya dukung ijin group pondasi tiang bor lebih besar dari beban luar group:

$\mathrm{Q}_{\text {all G }}>3 \mathrm{~N}$--- 705.4 Ton $>93,82$ Ton

3. Settlement pondasi tiang tunggal bor akibat beban luar lebih kecil dari Settlemen ijin pondasi tiang tunggal:

$\mathrm{S}<\mathrm{S}_{\text {all }}---0,63 \mathrm{~cm}<0,94 \mathrm{~cm}$

4. Settlement pondasi group tiang bor akibat beban luar;

Settlement group tiang akibat beban lebih besar dari Settlement ijin group tiang:

$\mathrm{S}_{\mathrm{G}}<\mathrm{S}_{\text {all G- ---- }} 2,66 \mathrm{~cm}<3,92 \mathrm{~cm}$ 
Daya dukung pondasi serta settlement akibat beban rencana memenuhi factor keamanan yang disyaratkan.

\section{B. Saran}

Analisa daya dukung tanah atau daya dukung pondasi serta settlement yang akan terjadi akibat beban rencana banyak metode yang bisa digunakan baik formula empiris maupun analitis tetang daya dukung pondasi serta pengambilan data parameter tanah sebagai data untuk dikaji menggunakan metode yang berbeda.

Metode analisa daya dukung pondasi antara lain;

1. Static Analysis by utilizing soil strength.

2. Emperical analysis by utilizing standard field test;
A. Standard penetration test value.
B. Cone penetration value.
C. Pressuremeter tests.

3. Dynamic driving resistance;

A. By pile driving formulas.

B. By wave equation.

4. Full-scale pile load tests.

Dari beberapa metode yang digunakan tentunya akan memberikan nilai yang berbeda, selama formula serta metodenya benar dengan factor keamanan memenuhi syarat hal ini dapat digunakan sebagai rujukan untuk design.

\section{DAFTAR PUSTAKA}

[1] Berry Peter L (1987), An introduction TO Soil Mechanic, Mc Graw Hill Book Company England.

[2] Bowles, Joseph (1984) E. Foundation, Mc Graw - Hill, Inc.
[3] Bowles, Joseph E. (1984) Physical And Geotechnical Propertises Of Soils, Mc Graw - Hill, Inc.

[4] Das, Braja M. (1985) Principles Of Geotechnical Engineering, Hemisphere Publishing Coorporation.

[5] Nasution Sarifudin.M.Eng, Ir,. (1990) Stabilitas Tanah, ITB.

[6] Prakash (1987), Pile Foundation Engineering, London.

[7] Sutarman, Encu (2006), Pengaruh Adittive Kimia Terhadap Kuat Geser Tanah, ITB

[8] Sutarman, Encu (2003). Konsep Dan Aplikasi Mekanika Tanah, Penerbit Andi, Jogjakarta.

[9] Sutarman, Encu (2013). Konsep Dan Aplikasi Pengantar Teknik Sipil, Penerbit Andi, Jogjakarta.

[10] Sutarman, Encu (2017), Settlement Khas Beberapa Jenis Tanah, Jurnal Istek, Kajian Islam, Sains dan Teknologi, Fakultas Sainstek UIN SGD Bandung, Edisi Mei 2017 Volume X No 1. 